\title{
Effect of Inclusion of Lacquer (Rhus verniciflua Stokes) Meal on Carcass Traits and Meat Quality in Growing-finishing Pigs
}

\author{
Chang Hyun Song, Jin Soo Kim, Prashant Shinde, Young Woo Kim, Kwang Hyun Kim, III Kyung Kwon', \\ Sun Moon Kang ${ }^{1}$, Sung Ki Lee ${ }^{1}$, and Byung Jo Chae* \\ Department of Animal Resources Science, Kangwon National University, Chuncheon 200-701, Korea \\ ${ }^{1}$ Department of Animal Products and Food Science, Kangwon National University, Chuncheon 200-701, Korea
}

\begin{abstract}
In this study, pigs [ $\mathrm{n}=117$; (Landrace $\times$ Yorkshire) $\times$ Duroc; $64 \pm 0.5 \mathrm{~kg}$ initial body weight] were used to investigate the effect of feeding different levels of lacquer (Rhus verniciflua Stokes) meal on performance, carcass traits and quality of meat kept under refrigeration at $3 \pm 1^{\circ} \mathrm{C}$. The pigs were randomly allotted to 3 treatments on the basis of body weight and sex and each treatment was replicated 3 times (13 pigs in each replicate). Lacquer meal in sawdust form obtained from the stem bark and heartwood of sun-dried lacquer trees was added to the grower and finisher diets at 0,20 and $40 \mathrm{~g} / \mathrm{kg}$ diet. The experimental diets were fed for $8 \mathrm{wk}$. Inclusion of lacquer meal had no influence $(p>0.05)$ on growth performance of pigs. Improvement in carcass traits and decreased back fat thickness were noticed in pigs fed diets added with 20 and $40 \mathrm{~g} / \mathrm{kg}$ lacquer meal. Longissimus muscle obtained from pigs fed lacquer meal had higher moisture and lower fat content, thiobarbituric acid reactive substances and water holding capacity. Meat from lacquer fed pigs was also darker and redder. The data indicates that lacquer meal can be incorporated up to $40 \mathrm{~g} / \mathrm{kg}$ in the diet of fattening pigs without affecting growth performance. Also, lacquer meal increases carcass lean content and improves the oxidative stability of the meat.
\end{abstract}

Key words: carcass traits, lacquer (Rhus verniciflua Stokes) meal, meat quality, growing-finishing pig

\section{Introduction}

In recent years, there has been a trend towards the use of natural substances present in fruits, vegetables and herbs as antioxidants and functional foods (Farr, 1997). An increasing number of plant sources and by-products are being explored and studied for their phytochemicals and their potential benefits on animal productivity.

Lacquer (Rhus verniciflua) a plant of Anacardiaceae family, grows widely in Japan, China and Korea. It has been used as traditional medicine (Lee et al., 2003) and for the protection of antiquities (Kim, 1996). The sap of the lacquer tree is composed of urushiol (600 to $650 \mathrm{~g} /$ $\mathrm{kg}$ ), glycoprotein (21 to $18 \mathrm{~g} / \mathrm{kg}$ ), flavonoids (10 to $20 \mathrm{~g} /$ $\mathrm{kg}$ ) and gummy substance (60 to $70 \mathrm{~g} / \mathrm{kg}$ ) (Yang et al., 2002).

Supplementation of lacquer meal in the diet of Hanwoo cattle improved meat color stability and water holding

\footnotetext{
*Corresponding author: Byung Jo Chae, Department of Animal Resources Science, Kangwon National University, Chuncheon 200-701, Korea. Tel: 82-33-250-8616. Fax: 82-33-244-4946. E-mail: bjchae@kangwon.ac.kr
}

capacity, retarded lipid oxidation and extended storage life of meat (Kim et al., 2006). In broilers, inclusion of lacquer meal did not have any effect on growth performance, but improved fat digestibility and reduced serum levels of cholesterol and triglyceride (Lohakare et al., 2006). In our previous study, lacquer meal added to the finisher diets of pigs at 20 and $40 \mathrm{~g} / \mathrm{kg}$ reduced back fat and improved oxidative stability of meat but there was no effect on the growth performance and carcass traits (Song et al., 2008). Thus, the present study was conducted to further evaluate the effects of including lacquer meal in grower and finisher diets of fattening pigs on their performance, carcass characteristics and meat quality during refrigerated storage.

\section{Materials and Methods}

\section{Lacquer meal}

The lacquer meal used in the present study was obtained from Gapyeong Livestock Company (Gapyeong-gun, Gyeonggi-do, Korea). The stem bark and heartwood of the lacquer trees were sun-dried and then reduced to sawdust by an electrical mill. The sawdust was then passed 
through 2 to $3 \mathrm{~mm}$ mesh-screen and added as such to the grower and finisher diets.

\section{Animals and diets}

The study underwent proper ethical guidelines and was approved by the Animal Care and Use Committee of Kangwon National University. One hundred and seventeen growing pigs [(Landrace $\times$ Yorkshire $) \times$ Duroc; $64 \pm$ $0.5 \mathrm{~kg}$ average initial body weight; $120 \pm 10$ days of age] of mixed sex (63 boars and 54 gilts) were randomly allotted to three dietary treatments with three replicate pens in each (comprising 13 pigs per pen), on the basis of their body weights and sex ( 7 boars and 6 gilts). These pigs were housed in partially slotted and concrete floor pens having a pen size of $3.5 \mathrm{~m} \times 3.5 \mathrm{~m}$. Pens were equipped with a self-feeder and nipple waterer to allow ad libitum access to feed and water.

Lacquer meal was incorporated at 0,20 , and $40 \mathrm{~g} / \mathrm{kg}$ of the diet and isocaloric and isonitrogenous grower and finisher diets were formulated. The experimental feeding was conducted for $8 \mathrm{wk}$ : 0 to $3 \mathrm{wk}$ (grower diet) and 4 to $8 \mathrm{wk}$ (finisher diet). Grower diets were formulated to contain $13.81 \mathrm{MJ} / \mathrm{kg} \mathrm{ME}$ and $1.10 \%$ lysine and finisher diets were formulated to contain $13.81 \mathrm{MJ} / \mathrm{kg} \mathrm{ME}$ and $0.95 \%$ lysine (Table 1 ). All the diets met or exceeded the nutrient requirements as suggested by NRC (1998).

Table 1. Formula and chemical composition of the experimental diets

\begin{tabular}{|c|c|c|c|c|c|c|}
\hline \multirow{2}{*}{$\begin{array}{c}\text { Item } \\
\text { Lacquer meal }(\mathrm{g} / \mathrm{kg})\end{array}$} & \multicolumn{3}{|c|}{ Grower (0 to $3 \mathrm{wk})$} & \multicolumn{3}{|c|}{ Finisher (4 to $8 \mathrm{wk}$ ) } \\
\hline & 0 & 20 & 40 & 0 & 20 & 40 \\
\hline \multicolumn{7}{|l|}{ Ingredient $(\mathrm{g} / \mathrm{kg})$} \\
\hline Maize & 588.9 & 551.5 & 508.0 & 662.4 & 624.6 & 582.7 \\
\hline Ricebran & 50.0 & 50.0 & 50.0 & 50.0 & 50.0 & 50.0 \\
\hline Dehulled-SBM & 274.0 & 278.5 & 285.0 & 202.0 & 209.0 & 216.0 \\
\hline Animal fat & 22.0 & 35.0 & 52.0 & 20.0 & 34.0 & 49.0 \\
\hline Molasses & 35.0 & 35.0 & 35.0 & 38.0 & 35.0 & 35.0 \\
\hline L-lysine & 1.2 & 1.1 & 1.0 & 1.8 & 1.6 & 1.5 \\
\hline $\mathrm{DL}^{- \text {-methionine }}$ & 0.3 & 0.3 & 0.4 & 0.2 & 0.2 & 0.3 \\
\hline Choline chloride & 0.4 & 0.4 & 0.4 & 0.4 & 0.4 & 0.4 \\
\hline Bactacid $^{1)}$ & 1.0 & 1.0 & 1.0 & 1.0 & 1.0 & 1.0 \\
\hline Dicalcium phosphate & 11.5 & 11.5 & 11.5 & 9.0 & 9.0 & 9.1 \\
\hline Limestone & 8.5 & 8.5 & 8.5 & 8.0 & 8.0 & 7.8 \\
\hline Salt & 3.0 & 3.0 & 3.0 & 3.0 & 3.0 & 3.0 \\
\hline Mineral premix ${ }^{2)}$ & 2.0 & 2.0 & 2.0 & 2.0 & 2.0 & 2.0 \\
\hline Vitamin premix ${ }^{3)}$ & 1.2 & 1.2 & 1.2 & 1.2 & 1.2 & 1.2 \\
\hline Probiotic product ${ }^{1)}$ & 1.0 & 1.0 & 1.0 & 1.0 & 1.0 & 1.0 \\
\hline Lacquer meal & 0.0 & 20.0 & 40.0 & 0.0 & 20.0 & 40.0 \\
\hline \multicolumn{7}{|l|}{ Chemical composition (\%) } \\
\hline $\mathrm{ME}(\mathrm{MJ} / \mathrm{kg})^{4)}$ & 13.81 & 13.81 & 13.81 & 13.81 & 13.81 & 13.81 \\
\hline $\mathrm{CP}^{5)}$ & 18.77 & 18.70 & 18.68 & 16.00 & 16.34 & 16.27 \\
\hline Ether extract ${ }^{5)}$ & 5.40 & 6.53 & 8.06 & 5.33 & 6.60 & 7.92 \\
\hline Crude fiber ${ }^{5)}$ & 4.24 & 5.27 & 6.29 & 4.10 & 5.08 & 6.11 \\
\hline Total $\operatorname{ash}^{5)}$ & 5.40 & 5.76 & 6.13 & 4.75 & 5.10 & 5.47 \\
\hline Calcium $^{4)}$ & 0.70 & 0.70 & 0.70 & 0.60 & 0.60 & 0.60 \\
\hline Available phosphorus ${ }^{4)}$ & 0.30 & 0.30 & 0.30 & 0.25 & 0.25 & 0.25 \\
\hline Lysine $^{4)}$ & 1.10 & 1.10 & 1.10 & 0.95 & 0.95 & 0.95 \\
\hline Methionine + Cystine $^{4)}$ & 0.65 & 0.65 & 0.65 & 0.57 & 0.57 & 0.57 \\
\hline
\end{tabular}

${ }^{1}$ Bactacid: organic acid product obtained from Koren Milk Product Inc. (Gyeonggi-do, Korea). Probiotic product: Worldlab (CTC BIO, Seoul, Korea).

${ }^{2)}$ Supplied per kg diet: 150 mg Fe, 96 mg Cu, 72 mg Zn, 46.5 mg Mn, 0.9 mg I, 0.9 mg Co, 0.3 mg Se.

${ }^{3}$ Supplied per kg diet: For grower diets: 8,960 IU vitamin A, 1,680 IU vitamin D3, $22.4 \mathrm{mg}$ vitamin E, $1.4 \mathrm{mg}$ vitamin B1, $11.2 \mathrm{mg}$ vitamin B2, $2.2 \mathrm{mg}$ vitamin B6, $0.042 \mathrm{mg}$ vitamin B12, $1.4 \mathrm{mg}$ vitamin $\mathrm{K} 3,22.4 \mathrm{mg}$ pantothenic acid, $42 \mathrm{mg}$ niacin, $0.084 \mathrm{mg}$ biotin, $0.364 \mathrm{mg}$ folic acid. For finisher diets: 8,000 IU vitamin A, 1,500 IU vitamin D3, $16 \mathrm{mg}$ vitamin E, $1.0 \mathrm{mg}$ vitamin B1, $8.0 \mathrm{mg}$ vitamin B2, $1.6 \mathrm{mg}$ vitamin B6, $0.03 \mathrm{mg}$ vitamin B12, $1.0 \mathrm{mg}$ vitamin $\mathrm{K} 3,16 \mathrm{mg}$ pantothenic acid, $30 \mathrm{mg}$ niacin, $0.06 \mathrm{mg}$ biotin, $0.26 \mathrm{mg}$ folic acid.

${ }^{4)}$ Calculated values.

${ }^{5)}$ Analyzed values. 


\section{Experimental procedures and measurements}

The pigs were weighed individually and feed consumption per pen was measured at the end of each phase. The overall average daily gain (ADG), average daily feed intake (ADFI) and feed efficiency (F/G) were calculated.

At the end of the experiment, six pigs ( 3 boars and gilts) from each replicate weighing $110 \mathrm{~kg}$ were transported $60 \mathrm{~km}$ to a commercial slaughter house after overnight fasting. After resting for $3 \mathrm{~h}$, pigs were electrically stunned, slaughtered by bleeding and eviscerated. The hot carcass weights were taken immediately after the final wash and before the carcasses were moved to the chill cooler. The carcasses were then dissected and placed in the chiller $\left(4^{\circ} \mathrm{C}\right)$. The carcass traits were obtained from the left side of each carcass, following $24 \mathrm{~h}$ chilling. Loin eye area was determined immediately after excision by tracing the longissimus muscle surface area at the 10th rib and by using a compensating polar planimeter. Backfat thickness was measured at the 10th rib, three-quarters of the lateral length of the longissimus muscle (LM) perpendicular to the outer skin surface using a vernier caliper (Mitutoyo Co., Kawasaki, Japan). Fat free lean percent was estimated using NPPC (1991) equation and adjusted to lean containing $0 \%$ fat.

After $24 \mathrm{~h}$ chilling of carcass at $4^{\circ} \mathrm{C}$, the right LM was removed and the chemical composition and meat quality was measured. The LM was trimmed of all external fat and sectioned into $2.54 \mathrm{~cm}$ chops and packed using polyethylene wrap film (oxygen transmission rate $35.723 \mathrm{cc} /$ $\mathrm{m}^{2} \cdot$ atm, thickness $0.01 \mathrm{~mm}, 3 \mathrm{M}$ Co., Seoul, Korea). The samples for the analysis of chemical composition were stored at $-30^{\circ} \mathrm{C}$, whereas those used for the analysis of meat quality were stored at $3 \pm 1^{\circ} \mathrm{C}$ for 5 or $10 \mathrm{~d}$. Also, a section of loins were utilized for the analysis of CIE color score, $\mathrm{pH}$, thiobarbituric acid reactive substances (TBARS) and water holding capacity (WHC) to obtain 0 day values (24 h postmortem).

A color difference meter (Co., CR-310 Minolta, Japan) was used to determine CIE L (lightness), a (redness) and $\mathrm{b}$ (yellowness) values at day 0,5 and $10 \mathrm{~d}$ of refrigerated storage. The surface color of loins was measured through the packaging film following calibration against a white tile covered with the same film. Individual packages were used for repeated measurements and remained intact during the entire storage period. One part of loin sample was homogenized in 9 parts of distilled deionized water and used for measuring $\mathrm{pH}$ (F-12, Horiba, Japan). The $\mathrm{pH}$ was measured immediately after sectioning of loins on $\mathrm{d}$ 0 , and after $10 \mathrm{~min}$ bloom on 5 and $10 \mathrm{~d}$ of refrigerated storage. The WHC was measured by the filter-paper press method as indicated by Grau and Hamm (1953). TBARS assay was performed as described by Sinnhuber and Yu (1977) and values were expressed as mg malonaldehyde/ kg sample.

\section{Chemical analyses}

Representative samples of lacquer meal and minced LM chops were analyzed for crude protein (954.01), crude fat (954.02), moisture (934.01) and ash (942.05) according to Association of Official Analytical Chemists (1995) methods. Total flavonoids present in crude ethanol extract of lacquer meal were determined by aluminium nitrate colorimetric method as described by Mohammadzadeh et al. (2007). Quercetin was used as a standard compound in the range of 5 to $100 \mu \mathrm{g} / \mathrm{mL}$ concentration to construct a standard curve and the amount of total flavonoids expressed as quercetin equivalent.

\section{Statistical analyses}

The data was subjected to one-way ANOVA to determine significant differences among treatments by using SAS software (SAS Inst., Inc., Cary, NC, 1998). The pen was the experimental unit for the analysis of all traits. When significant differences were noted $(p<0.05)$, means were separated using Duncan's multiple range tests.

\section{Results}

The lacquer meal used in this study had 14.9 MJ gross energy, $13.9 \mathrm{~g}$ crude protein, $53.1 \mathrm{~g}$ ether extract, $545.0 \mathrm{~g}$ crude fiber and $817.0 \mathrm{~g}$ neutral detergent fiber per $\mathrm{kg}$ (Table 2). The flavonoids present was $41.2 \mathrm{~g}$ quercetin equivalent per $\mathrm{kg}$ of lacquer meal.

There were no effects of lacquer meal inclusion on the overall growth performance of pigs (data not shown). The

Table 2. Chemical composition of lacquer meal (on dry matter basis) used during the feeding trial

\begin{tabular}{lr}
\hline \multicolumn{1}{c}{ Item } & $\mathrm{g} / \mathrm{kg}$ \\
\hline Dry matter & 814.0 \\
Gross energy $(\mathrm{MJ} / \mathrm{kg})$ & 14.9 \\
Crude protein & 13.9 \\
Ether extract & 53.1 \\
Crude fiber & 545.0 \\
Neutral detergent fiber & 817.0 \\
Total Ash & 188.0 \\
Calcium & 4.4 \\
Phosphorus & 1.2 \\
Total flavonoid & 41.2 \\
\hline
\end{tabular}


inclusion of lacquer increased $(p<0.05)$ the dressing percentage, loin eye area and fat free lean percent and decreased backfat thickness (Table 3).

The LM of pigs fed lacquer diets had higher $(p<0.05)$ moisture and lower $(p<0.05)$ crude fat content, while the crude protein remained unaffected (Table 4).

Table 3. Effect of lacquer meal on carcass characteristics of longissimus muscle

\begin{tabular}{ccccc}
\hline \hline \multirow{2}{*}{ Items } & \multicolumn{3}{l}{ Lacquer meal $(\mathrm{g} / \mathrm{kg})$} & \\
\cline { 2 - 4 } & S.E.M. ${ }^{1)}$ \\
\hline
\end{tabular}

Carcass characteristics

$\begin{array}{lllll}\text { Dressing percentage } \quad 77.37^{\mathrm{b}} & 78.52^{\mathrm{a}} & 78.79^{\mathrm{a}} & 0.15\end{array}$

$\begin{array}{lllll}\text { Backfat thickness }(\mathrm{mm}) & 25.00^{\mathrm{a}} & 22.67^{\mathrm{b}} & 21.83^{\mathrm{b}} & 0.32\end{array}$

$\begin{array}{lllll}\text { Loin eye area }\left(\mathrm{cm}^{2}\right) & 52.32^{\mathrm{b}} & 53.37^{\mathrm{ab}} & 54.00^{\mathrm{a}} & 0.34\end{array}$

$\begin{array}{lllll}\text { Fat free lean percentage } \quad 57.25^{\mathrm{b}} & 58.23^{\mathrm{a}} & 58.61^{\mathrm{a}} & 0.14\end{array}$

$\overline{\mathrm{a}, \mathrm{b}}$ Means with different superscripts in the same row differ significantly $(p<0.05)$.

${ }^{1)}$ S.E.M., standard error of the mean.

Table 4. Effect of lacquer meal on chemical composition of longissimus muscle

\begin{tabular}{lcccc}
\hline \hline \multirow{2}{*}{ Items } & \multicolumn{3}{c}{ Lacquer meal $(\mathrm{g} / \mathrm{kg})$} & \\
\cline { 2 - 4 } & 0 & 20 & 40 & S.E.M. ${ }^{1)}$ \\
\hline Composition of longissimus muscle $(\mathrm{g} / \mathrm{kg})$ & & \\
Moisture & $735.3^{\mathrm{b}}$ & $740.6^{\mathrm{a}}$ & $741.0^{\mathrm{a}}$ & 1.24 \\
Crude protein & 231.0 & 231.3 & 232.0 & 1.56 \\
Crude fat & $27.1^{\mathrm{a}}$ & $18.6^{\mathrm{b}}$ & $17.3^{\mathrm{b}}$ & 1.56 \\
Crude ash & $10.5^{\mathrm{a}}$ & $10.0^{\mathrm{b}}$ & $10.3^{\mathrm{ab}}$ & 0.52 \\
\hline
\end{tabular}

$\overline{\mathrm{a}, \mathrm{b}}$ Means with different superscripts in the same row differ significantly $(p<0.05)$.

${ }^{1)}$ S.E.M., standard error of the mean.

Table 5. Effect of lacquer meal on meat color during storage at $3 \pm 1^{\circ} \mathrm{C}$

\begin{tabular}{crrrrr}
\hline \hline \multirow{2}{*}{ Items } & $\begin{array}{c}\text { Storage } \\
\text { day }\end{array}$ & \multicolumn{4}{c}{ Lacquer meal (g/kg) } \\
\cline { 3 - 5 } & \multicolumn{5}{c}{ S.E.M. ${ }^{1)}$} \\
\hline \multirow{5}{*}{$\mathrm{L}$} & 0 & 53.95 & 52.78 & 53.66 & 0.26 \\
& 5 & 54.25 & 54.07 & 53.62 & 0.21 \\
& 10 & $54.89^{\mathrm{a}}$ & $53.93^{\mathrm{b}}$ & $53.32^{\mathrm{b}}$ & 0.21 \\
\hline \multirow{3}{*}{$\mathrm{a}^{*}$} & 0 & $5.95^{\mathrm{b}}$ & $8.31^{\mathrm{a}}$ & $7.69^{\mathrm{a}}$ & 0.26 \\
& 5 & $5.58^{\mathrm{b}}$ & $7.41^{\mathrm{a}}$ & $6.99^{\mathrm{a}}$ & 0.20 \\
& 10 & $3.31^{\mathrm{b}}$ & $4.30^{\mathrm{a}}$ & $4.14^{\mathrm{a}}$ & 0.17 \\
\hline \multirow{4}{*}{$\mathrm{b}^{*}$} & 0 & $6.80^{\mathrm{a}}$ & $5.15^{\mathrm{c}}$ & $5.92^{\mathrm{b}}$ & 0.16 \\
& 5 & $7.19^{\mathrm{a}}$ & $5.97^{\mathrm{b}}$ & $6.28^{\mathrm{b}}$ & 0.10 \\
& 10 & $6.81^{\mathrm{a}}$ & $4.95^{\mathrm{ab}}$ & $5.73^{\mathrm{b}}$ & 0.19 \\
& 5 & $46.58^{\mathrm{a}}$ & $43.91^{\mathrm{b}}$ & $42.16^{\mathrm{b}}$ & 1.45 \\
& 10 & $55.69^{\mathrm{a}}$ & $50.31^{\mathrm{b}}$ & $49.28^{\mathrm{b}}$ & 0.94 \\
\hline
\end{tabular}

$\overline{\mathrm{a}, \mathrm{b}, \mathrm{c}}$ Means with different superscripts in the same row differ significantly $(p<0.05)$.

${ }^{1)}$ S.E.M., standard error of the mean.
Table 6. Effect of lacquer meal on $\mathrm{pH}$, TBARS and WHC during refrigerated storage at $3 \pm 1^{\circ} \mathrm{C}$

\begin{tabular}{cccccc}
\hline \hline \multirow{2}{*}{ Items } & \multirow{2}{*}{$\begin{array}{c}\text { Storage } \\
\text { day }\end{array}$} & \multicolumn{4}{c}{ Lacquer meal $(\mathrm{g} / \mathrm{kg})$} \\
\cline { 3 - 5 } & 0 & 20 & 40 & \multirow{2}{*}{ S.E.M. ${ }^{1)}$} \\
\hline \multirow{2}{*}{$\mathrm{pH}$} & 0 & 5.50 & 5.43 & 5.49 & 0.04 \\
& 5 & 5.59 & 5.44 & 5.53 & 0.05 \\
& 10 & 5.60 & 5.51 & 5.58 & 0.05 \\
\hline \multirow{2}{*}{ TBARS } & 0 & $0.14^{\mathrm{a}}$ & $0.10^{\mathrm{b}}$ & $0.09^{\mathrm{b}}$ & 0.01 \\
$(\mathrm{mg} \mathrm{MA} / \mathrm{kg})$ & 5 & 0.24 & 0.22 & 0.23 & 0.01 \\
& 10 & $0.35^{\mathrm{a}}$ & $0.30^{\mathrm{b}}$ & $0.27^{\mathrm{b}}$ & 0.01 \\
\hline \multirow{3}{*}{ WHC $(\%)$} & 0 & $35.97^{\mathrm{a}}$ & $33.97^{\mathrm{b}}$ & $31.22^{\mathrm{c}}$ & 0.43 \\
& 5 & $46.58^{\mathrm{a}}$ & $43.91^{\mathrm{b}}$ & $42.16^{\mathrm{b}}$ & 1.45 \\
& 10 & $55.69^{\mathrm{a}}$ & $50.31^{\mathrm{b}}$ & $49.28^{\mathrm{b}}$ & 0.94 \\
\hline
\end{tabular}

a, b, ${ }^{c}$ Means with different superscripts in the same row differ significantly $(p<0.05)$.

${ }^{1)}$ S.E.M., standard error of the mean.

The CIE $\mathrm{L}$ values of $\mathrm{LM}$ after refrigeration remained unaffected at $0 \mathrm{~d}$ and 5 , while at $10 \mathrm{~d}$ of storage, LM of pigs fed lacquer diets had lower $(p<0.05)$ CIE $\mathrm{L}$ values (Table 5). Pigs fed lacquer diets had higher CIE a ( $p<$ 0.05 ) and lower CIE b values at 0,5 , and $10 \mathrm{~d}$ of refrigerated storage.

The TBARS (day 0 , and 10 ) and WHC (day 0,5 , and 10) were lower in the LM obtained from pigs fed lacquer diet, however the TBARS at $\mathrm{d} 5$ and the $\mathrm{pH}$ values at $\mathrm{d} 0$, 5 , and 10 of refrigerated storage were not influenced by incorporation of lacquer in the diet (Table 6).

\section{Discussion}

Lacquer meal was supplemented in the diet of pigs to study its effects on performance, carcass characteristics and meat quality. The experimental diets were made isoenergetic by replacing parts of maize by animal fat in diets incorporated with lacquer meal and thus the ether extract was higher in these diets than control diets. Similar to the findings of the current study, no growth performance benefits were reported in broilers (Lohakare et al., 2006) and finisher pigs (Song et al., 2008) when their diets were supplemented with lacquer meal at 20 and 40 $\mathrm{g} / \mathrm{kg}$ diet.

In the current study, addition of lacquer meal improved dressing percent, loin eye area and fat free lean percent; moreover the lipid content of LM was decreased in pigs fed lacquer diets. In contrast, Lohakare et al. (2006) did not find any changes in the carcass characteristics of broilers supplemented with lacquer meal. However, Kim et al. (2006) reported reductions in the lipid content of 
LM in Hanwoo cattle that were fed with $60 \mathrm{~g} / \mathrm{kg}$ lacquer added diet which is in agreement with the findings of the current study. The changes towards lower back fat thickness and fat content in the muscle of pigs fed lacquer meal might be due to the flavonoid content of these diets. Flavonoids are known to reduce body fat mass (Tominaga et al., 2006) and abdominal fat accumulation (Nakagawa et al., 2004).

The $\mathrm{pH}$ values observed in our study at $24 \mathrm{~h}$ postmortem were within the range of 5.4-5.5 reported by Briskey and Wiser-Pedersen (1961). The ability of muscle cells to entrap water is directly effected by $\mathrm{pH}$, ionic strength, and the oxidation of myofibrillar protein and myofibrils (Huff-Lonergan and Lonergan, 2005). In the current study, LM of pigs fed lacquer diets had lower TBARS and $\mathrm{WHC}$ during refrigerated storage. A lower $\mathrm{pH}$ denatures myofibrillar proteins and consequently, they bind less water (Hamm, 1986). The $\mathrm{pH}$ of loins obtained from pigs fed lacquer was numerically lower which might partially explain their lower WHC values.

Lipid oxidation is a major cause of deterioration in the quality of muscle foods and can directly affect quality characteristics such as flavor, color, texture, nutritive value and safety of the food (Buckley et al., 1995). The loss of redness of meat during storage is caused by oxidation of the bright pinkish-red oxymyoglobin to the brown metmyoglobin (Faustman and Cassens, 1990). Improved oxidative stability may reduce the rate of such oxidation and preserve the red color for a longer time during storage which might explain the higher CIE a values in loins of pigs fed lacquer diets. Similar reductions in the TBARS values during refrigerated storage were reported by Kim et al. (2006) and Kang et al. (2008) in LM of Hanwoo cattle. Lower $\mathrm{L}$ values observed on d 10 of refrigerated storage indicate that meat of pigs fed lacquer is dark in color which is a desirable color based on consumer preference (Bates et al., 2005). The LM of pigs fed lacquer had lower yellow (CIE b) values during all storage days. Darker and less yellow loins from pigs fed lacquer might also be related to the antioxidant component flavonoid present in lacquer. The changes in the color, TBARS and WHC were similar to those noticed in our previous study in finishing pigs (Song et al., 2008). In line with the findings of the present study, significant improvements in a and lower $\mathrm{L}$ values have been reported in pigs supplemented with á-tocopherol (Mason et al., 2005), whereby suggesting that antioxidants might influence the meat color. Larrain et al. (2008) had also noticed alterations in the time course changes of color measurements in bacon of pigs fed flavonoid rich cranberry diet.

\section{Acknowledgement}

The authors sincerely acknowledge the financial support provided by the Institute of Animal Resources at Kangwon National University, Korea.

\section{References}

1. AOAC (1995) Official Methods of Analysis. 16th ed, Association of Official Analytical Chemists, Washington, DC, USA.

2. Bates, R. O., May, J., Guthrie, T., and Rozeboom, D. (2005) Green and white show meat quality evaluation. Pork Quaterly 10, 5-9.

3. Briskey, E. J. and Wismer-Pedersen, J. (1961) Biochemistry of pork muscle structure. I. Rate of anaerobic glycolysis and temperature change versus the apparent structure of muscle tissue. J. Food Sci. 26, 297-305.

4. Buckley, D. J., Morrissey, P. A., and Gray, J. I. (1995) Influence of dietary vitamin $\mathrm{E}$ on the oxidative stability and quality of pig meat. J. Anim. Sci. 71, 3122-3130.

5. Farr, D. R. (1997) Functional foods. Cancer Lett. 114, 59-63.

6. Faustman, C. and Cassens, R. G. (1990) The biochemical basis for discoloration in fresh meat. A review. J. Muscle Foods 1, 217-343.

7. Grau, R. and Hamm, R. (1953) Eine einfache methode zur bestimmung der wasserbindung in muskel. Naturwissenschaften 40, 29.

8. Hamm, R. (1986) Current problems in meat research. Fleischwirtschaft 66, 1772-1776.

9. Huff-Lonergan, E. and Lonergan, S. M. (2005) Mechanisms of water-holding capacity of meat: The role of postmortem biochemical and structural changes. Meat Sci. 71, 194-204.

10. Kang, S. M., Kim, Y. S., Liang, C. Y., Song, Y. H., and Lee, S. K. (2008) Effect of feeding periods of dietary Rhus verniciflua Stokes on the quality characteristics of Hanwoo beef during refrigerated storage. Korean J. Food Sci. Ani. Resour. 28, 401-407.

11. Kim, T. J. (1996) Korean Resource Plants, Vol. II. Seoul National University Press, Seoul, Korea. pp. 292-297.

12. Kim, Y. S., Liang, C. Y., Song, Y. H., and Lee, S. K. (2006) Effects of dietary Rhus verniciflua Stokes supplementation on meat quality characteristics of Hanwoo (Korean cattle) beef during refrigerated storage. Asian-Aust. J. Anim. Sci. 19, 113-118.

13. Larrain, R. E., Krueger, C. G., Richards, M. P., and Reed, J. D. (2008) Color changes and lipid oxidation in pork products made from pigs fed with cranberry juice powder. J. Muscle Foods 19, 17-33.

14. Lee, J. C., Kim, J., and Jang, Y. S. (2003) Ethanol eluted extract of Rhus verniciflua Stokes inhibits cell growth and induces apotosis in human lymphoma cells. J. Biochem. Mol. Bio. 36, 337-343. 
15. Lohakare, J. D., Zheng, J., Yun, J. H., and Chae, B. J., (2006). Effects of lacquer (Rhus verniciflua) supplementation on growth performance, nutrient digestibility, carcass traits and serum profile of broiler chickens. Asian-Aust. J. Anim. Sci. 19, 418-424.

16. Mason, L. M., Hogan, S. A., Lynch, A., Sullivan, K. O., Lawlor, P. G., and Kerry, J. P. (2005) Effects of restricted feeding and antioxidant supplementation on pig performance and quality characteristics of longissimus dorsi muscle from Landrace and Duroc pigs. Meat Sci. 70, 307-317.

17. Mohammadzadeh, S., Sharriatpanahi, M., Hamedi, M., Amanzadeh, Y., Ebrahimi, S. E. S., and Ostad, S. N. (2007) Antioxidant power of Iranian propolis extract. Food Chem. 103, 729-733.

18. Nakagawa, K., Kishida, H., Arai, N., Nishiyama, T., and Mae, T. (2004) Licorice flavonoids suppress abdominal fat accumulation and increase in blood glucose level in obese diabetic KK-A(y) mice. Biol. Pharma. Bull. 27, 1775-1778.

19. NPPC (1991) Procedures to Evaluate Market Hogs. 3rd ed, National Pork Producers Council, Des Moines, IA, USA.

20. NRC (1998) Nutrient Requirements of Swine. 10th ed, National Academy Press, Washington, DC.
21. Sinnhuber, R. O. and Yu, T. C. (1977) The 2-thiobarbituric acid reaction, an objective measure of the oxidative determination occurring in fats and oils. J. Jan. Soc. Fish Sci. 26, 259-267.

22. SAS. 1988. SAS/STAT® Users Guide, Release 6.03 ed, SAS Inst. Inc., Cary, NC.

23. Song, C. H., Choi, J. Y., Yoon, S. Y., Yang, Y. X., Shinde, P. L., Kwon, I. K., Kang, S. M., Lee, S. K., and Chae, B. J. (2008) Effects of lacquer (Rhus verniciflua) meal on carcass traits, fatty acid composition and meat quality of finishing pigs. Asian-Aust. J. Anim. Sci. 21, 1207-1213.

24. Tominaga, Y, Mae, T., Kitano, M., Sakamoto, Y., Ikematsu, H., and Nakagawa, K. (2006) Licorice flavonoid oil effects body weight loss by reduction of body fat mass in overweight subjects. J. Health Sci. 52, 672-683.

25. Yang, J., Du, Y., Huang, R., Wan, Y., and Li, T. (2002) Chemical modification, characterization and structure-anticoagulant activity relationships of Chinese lacquer polysaccharides. Int. J. Biol. Macromol. 31, 55-62.

(Received 2010.3.11/Revised 2010.6.23/Accepted 2010.7.4) 